\title{
Low-cost policy specialization, district characteristics and gender. Patterns of committee assignment in Romania
}

\author{
Mihail Chiru ${ }^{1}$, Oxford School of Global and Area Studies, Oxford, UK
}

Committee assignment can influence the efficiency of legislative work, the success of parties in reaching their policy goals and even the electoral fates of individual legislators. Nevertheless, little is known about this process in the legislatures established in the Central and Eastern European democracies. These legislatures faced severe informational, electoral and partisan challenges which raised the stakes of efficient committee-seat allocation. Simultaneously, most parliaments in the region were endowed with strong committees. The Romanian Parliament is representative for this combination of conditions. Drawing on a dataset that covers the careers, sector knowledge, partisan and electoral attributes of all the members serving in five terms of the Chamber of Deputies the article shows that committee assignment is used to facilitate low-cost policy specialization, district characteristics matter for gaining seats in committees with distributive potentials, while female legislators are confined to committees dealing with feminised policy areas.

Keywords: committee assignment; legislative organization; political parties; Romania;

\section{Funding}

Mihail Chiru' s work was supported by the Universit catholiqué de Louvain through the 'MOVEIN Louvain' Incoming Post-doctoral Fellowship, co-funded by the Marie Curie Actions of the European Commission.

\footnotetext{
${ }^{1}$ Email address: mihail.chiru@area.ox.ac.uk, phone: 07518407676; postal address: 11 Bevington Road, UK, OX2 $6 \mathrm{NB}$.
} 


\section{Introduction}

Committee assignment is widely believed to influence the efficiency of legislative work, the extent to which parties can reach their policy goals and even the electoral fates of individual legislators (Martin 2014). Nevertheless, very little is known about the determinants of this process in the legislatures established in democracies established in the Central and Eastern Europe (CEE) after 1989 (Ylaoutinen and Hallerberg 2009). In the first two decades since the regime change, these legislatures faced a series of severe challenges which raised the stakes of efficient committee seat allocation: very little parliamentary expertise to be mobilised, high electoral volatility and ideologically fuzzy political parties frequently affected by splits and party switching (Chiru and Gherghina 2017). At the same time, most of the committees in the region were endowed by design with significant powers (Andre et al 2016). The Romanian Parliament is a representative case for this combination of conditions. This article uses a data set that includes information on the careers, sector knowledge, partisan and electoral attributes of all the members of the Romanian Chamber of Deputies (lower chamber of the Parliament) who have served between 1992 and 2012, to test a number of hypotheses regarding committee membership derived mostly from congressional theories of legislative organization. The article presents a comprehensive longitudinal exploration of committee assignment in the parliament of one postcommunist democracy. It does so by differentiating between parliamentary committees based on two criteria: their type of output (e.g. distributive, public goods or high policy committees) and their perceived importance according to the legislators themselves. The introduction is followed by a discussion of the theoretical models of committee assignment which inspired this study and how some of their assumptions need to be adapted for young democracies. I then present the main expectations of the study, which is followed by a section describing the features of parliamentary committees in Romania. Next come the research design details: the data sources, variables' operationalization and methods. The sixth section discusses the results of the multivariate analyses. The conclusions synthesise the main findings and suggest further directions of research.

\section{Adapting theories of committee assignment to transition legislatures}

Three of the legislative organization theories originating in the study of the US Congress remain the theoretical backbone of comparative analyses of committee assignment: the informational perspective, the distributive approach and the partisan perspective. The scholarship testing these theories using data from European legislatures focused often on advanced Western European democracies. A notable exception is the study of committee assignment in Turkey by Ciftci et al. (2008). The article will help fill this gap by drawing on data from five legislative terms in Romania, a country that exhibits many of the typical institutional and party system features which affect the institutionalization of committees and the establishment of committee assignment procedures in young democracies.

One major challenge faced by legislatures in these countries was to set up 'an internal structure of effective organization and regularised procedure, while simultaneously processing a wide range of policy decisions' (Olson and Crowther 2002: 4). This had to be done in the absence of relevant parliamentary expertise and while anticipating possible patterns of cooperation and conflict between the legislature and the executive. In the end, most of the committees in the CEE 
parliaments were modelled after the US example and received extensive powers (Andre et al 2016).

Another relevant feature which might affect the committee assignment process is the ideological fuzziness of political parties in CEE (Millard 2004; Spirova 2007). In Romania, parties frequently changed their policy positions and even their general ideological orientation (Frye 2002; Gherghina and Chiru 2013), in pragmatic attempts to occupy the space in the political landscape left empty by the failure of other competitors. In such a context, parties are probably not as 'desperate' as their counterparts in systems with stronger programmatic linkages to use parliamentary committees to achieve their policy goals. Moreover, MPs themselves would be less certain about the policy positions of the party, which they are supposed to defend in committee work.

The high electoral volatility of young democracies (Mainwaring et al 2017) makes unlikely any electoral gains from individual parliamentary behaviour, including committee activity. High electoral volatility also generates considerable legislative turnover, which in turn impedes the policy specialization of legislators and the development of seniority-based committee rules. Electoral volatility also attracts organizational instability: party elites often abandon sinking parties either by starting a splinter party (Ibenskas and Sikk 2017) or via individual party switching. This instability can affect the continuity of committee membership, but it can also provide clues regarding the value of committee seats for individual legislators. Mershon and Shvetsova (2009) analyzed the timing of legislative party switching in Brazil, Italy, Russia, Romania, UK and US to understand the strategic rationales and type of benefits that motivate party-hoppers. Their evidence suggests that obtaining a seat in a more prestigious committee is not a key driver of party switching in Romania. Instead, most of the considerable party switching happening in the Parliament is related to supporting new parliamentary majorities or to seeking an easier re-election.

All of the aspects discussed above imply that some of the assumptions of committee-assignment theories need to be relaxed in order to make sense for the CEE context. First, policy-seeking motivations are less prevalent and are probably inferior to office-seeking motivations. Second, there are no established career-advancement formulas in which committee work would play a clear role (e.g. ministers might be recruited from outside the legislature, or politicians might take over party leadership without having a parliamentary career). Third, higher electoral uncertainty could work against a distributive logic of committee assignment: why strive to claim individual credit for certain policies or committee work if national swings in party popularity are driving election fortunes? The next paragraphs present our main expectations, which build upon the informational, distributional and partisan theories of legislative organization while taking into account the caveats discussed in this section.

\section{Theoretical expectations}

According to the informational theory, the main function of committees is to build the chamber's expertise in the respective policy areas, helping the legislature as a whole to pursue 'good policy'. Division of labour makes legislative work more efficient (i.e. many committees working in 
parallel on multiple issues) and the policies enacted follow the preferences of the legislature because the assignment process ensures committees are microcosms of the chamber (Gilligan and Krehbiel 1990). Indeed, the assignment of members to committees where they can specialise at low-cost due to their previous education or professional career is a pattern that was shown to hold in several European parliamentary democracies, under very different party systems and legislative organization rules (Mickler 2018a, Mickler 2018b, Espírito-Santo \& Sanches 2019). The very limited parliamentary expertise that parties can mobilise in young democracies coupled with the relatively high rates of legislative turnover they experience, should make policy specialization based on the expertise acquired previously by the MPs a very attractive option for the party leadership. Previous research has indeed shown that the selection of committee chairs in the Romanian legislature is driven mostly by informational and partisan credentials (Chiru and Gherghina 2017). Thus, MPs with sector knowledge regarding the committee's jurisdiction, those who have served as its chair in the past and party leaders are among the usual suspects for this office.

Put simply, the distributive theory maintains that legislators self-select to committees dealing with the policies that interest their constituents the most. Committees would be packed in this way with 'high demanders', ideological outliers that prefer more radical policy outcomes than the median legislator. Moreover, the committee members would engage in particularistic policy to maximise their re-election chances (Shepsle and Weingast, 1982). The explanatory potential of the distributive theory is limited in the context of an electoral system that does not create incentives for a personal vote (i.e. closed list PR) and where electoral volatility is relatively high. Moreover, in Romania, like in most European democracies (Martin 2011) the ability of individual legislators to pursue fiscal particularistic policy is severely constrained, because they cannot directly appropriate funds for local projects and the vast majority of individual amendments to the budget law are rejected. Nevertheless, even under CL PR, the MPs elected from smaller district magnitudes could still try to gain nomination in committees with a distributive potential in order to signal their responsiveness to constituents. This is what Riera and Cantú (2018) found to be the case for legislators in Norway, Portugal and Spain, the three closed list PR system included in their sample. Other district characteristics, beyond magnitude, could also play a similar role in the MPs' choice for a distributive committee: the share of constituents working in agriculture and the level of unemployment. Thus, MPs representing constituencies with a high level of unemployment or with a substantial share of citizens engaged in agriculture would have more incentives to seek a seat in a committee with distributive potential to signal that they are trying to improve the district's welfare, than to join a committee dealing with national policies (Martin 2014). Indeed, Raymond and Holt (2019) were able to show, drawing on a sample of 29 legislatures from Western Europe and Latin America that the proportion of legislators' "constituents employed in agriculture-related occupations is a major factor explaining assignment to agriculture committees and the effect is not mediated by electoral system features."

The partisan theory argues that parties use the committee assignment process to achieve two major goals: control the behaviour of their legislators and advance the policy positions they support (Cox and McCubbins, 1993). With respect to the former goal, the prediction is that parties would reward loyal MPs by assigning them to important committees and conversely, 
would send MPs that rebel at roll-call votes to serve in the least salient committees. ${ }^{13}$ Regarding the latter goal, we would expect members of the party leadership to be nominated to the most important committees or to those that deal with policies attracting the most media attention, i.e. high policy committees. As these national leaders are often the ones deciding the party's ideological stances (Riera and Cantú 2018) such nomination would ensure that the party's contingent in the committee is made aware of, and follows the policy priorities of the party (Chiru 2019). A self-selection mechanism might work in the same direction: party leaders would allocate themselves seats in the most prestigious committees, with an eye on future career advancement, within the party or at ministerial level. Moreover, if parties use committee assignment to pursue their policy goals, then they should encourage their MPs to specialise in certain policy areas so that they can represent better the party's positions in committees. As this process is likely to require continued presence in the legislature for several terms, parties might decide to deny access to important committees or committees that deal with policy areas that attract a lot of attention to those members that are at risk of losing their seats in the next elections (Hansen 2011: 351). Thus, we should observe parties nominating for the most important committees, as well as for those with a high policy profile those MPs who are less electorally vulnerable or more likely to be re-elected (Riera and Cantú 2018).

Gender perspectives to committee assignment emphasize that legislatures are mostly populated by males and party leaders who are the gatekeepers of committee positions are usually also male. Like many other CEE countries, Romania fits this pattern: throughout the period analysed, women remained under-represented in Parliament, to the extent that almost one in five districts failed to elect a single woman MP from 1992 to 2004 (Dubrow 2006). The overall share of women MPs varied between 5 and $7 \%$ in the first three terms analyzed here and stabilized around $11 \%$ in the following three legislatures. This under-representation can be at least partially explained by the fact that after the 1989 revolutions, societies in CEE have experienced a revival of traditional gender norms. Taken together these factors could amplify the discrimination of women MPs with respect to committee assignments. This would lead to stereotypical assignment of women to committees that deal with women's issues or policy areas that are associated with female roles and interests, at the expense of nomination in more powerful or more prestigious committees. While some studies found compelling evidence in this direction (Heath et al. 2005; Baekgaard and Kjaer 2012; Pansardi and Vercesi 2017) others failed to identify such effects or shown that they apply only to newcomer female legislators (Taylor-Robinson 2014).

Beyond the relationships discussed above I also control for the role of parliamentary seniority, age and time effects. In line with the informational logic, MPs with a longer career in the legislature might be rewarded with appointment in important committees or in those that are more policy-oriented, in order to use efficiently their knowledge of the legislative process and their social capital in the house (i.e. good relations developed with legislators from other parties). Older MPs are closer to retirement, thus, they should be less sensitive to the re-election concerns emphasized by the distributive theory. Therefore, they should be less likely to need either the visibility that comes from serving in high policy committees or to claim credit for policies adopted in distributive committees. The passage of time and the likely improvement of the legislature common pool of knowledge might modify the value party leaders place on some of the MPs' attributes discussed above (e.g. their professional expertise, their knowledge of 
parliamentary procedures) or their expectations regarding electoral rewards for policy work and signalling in the legislature. Such changes would likely affect the patterns of committee assignment.

\section{Parliamentary committees in Romania}

In the analysed period, the number of standing committees of the Chamber of Deputies has increased from 14 to 19 . Nevertheless, their policy jurisdictions and formal powers remained stable. With respect to the former one can observe considerable correspondence between the domains covered by the committees and the policy areas of ministries.

The formal powers of the committees tend to be substantial both in terms of information acquisition capacity and with respect to the committees' ability to rewrite the bills they are considering (Chiru and Gherghina 2017). All legislators are assigned to committees. According to the first Standing Orders of the Chamber (Regulamentul Camerei Deputatilor 1994) an MP can be member in only one standing committee, but this rule has been relaxed later on, to include two exceptions: MPs serving in the Rules committee or in the IT\&C committee can be also members of another standing committee. The standing committees can have between 11 and 41 $\mathrm{MPs}^{2}$, with the exception of the Rules committee, where each parliamentary party group (PPG) is represented by one MP. The PPGs nominate MPs for committees and the final committee composition has to be approved by all parties. In case of disagreement, the composition is decided by a simple majority vote in the plenary. The Standing Orders state that the assignment of committee seats to parties should follow the partisan composition of the House, but at least until the 2000s the proportional representation principle was not enforced strictly. Governing parties tended to be over-represented in committees dealing with policy areas they cared the most about or with topics that were high on the public agenda, such as NATO and EU integration during the 1996-2000 term (Roper 2004). Beyond formal powers, committees are also important in practice. Especially after the 2001 constitutional revision, more emphasis was put on committee work as opposed to plenary debates, and the committees' reports on bills increasingly shaped the time the bills are allocated for plenary debate and ultimately, their fate (Ionescu 2011).

\section{Data, variables and methods}

\subsection{Data sources}

The MPs' committee membership was retrieved from Tufis (2015a, 2015b, 2015c, 2015d, 2015e). The sector knowledge variable comes from Chiru and Gherghina (2017), while the information regarding the MPs' list positions originates from Chiru and Popescu (2017). The level of unemployment in county and the share of constituents working in agriculture were retrieved from the official statistics published by the National Institute of Statistics.

\subsection{The operationalization of variables}

In order to test the predictions of the legislative organization theories, the process of committee assignment is evaluated in two different ways: according to the committees' type of output of and 
by taking into consideration their salience relative to other committees, as perceived by the legislators.

Table 1 below presents the classification of committees according to their type of output. This follows Riera and Cantú (2018), but is also sensitive to the local context. Committees have a 'distributive' potential if the policies they adopt can generate benefits that target certain districts. On the contrary, 'public goods' committees deal with policies for which the benefits cannot be disaggregated, as they concern most citizens. 'High policy' committees include crucial areas such as finance, legal affairs and defence or more glamorous high politics domains such as foreign policy. These committees would generally attract more media attention (Riera and Cantú 2018: 528). A number of committees cannot be assigned unequivocally to any of the three types and are therefore included in the 'base' category. A special case is that of the economy committee, included in the base group, precisely because its features would warrant assignment to both high policy and public goods categories. For this and other similar situations, I chose assigning the borderline cases to the categories that ensured the highest comparability with previous research (Pekannen et al 2006; Riera and Cantú 2018).

While other studies rely on expert survey measures of cabinet portfolio salience and the close connection between ministerial portfolios and committees in order to rank committees for their importance (Hansen 2011), no similar data are available for Romania. Therefore, I rely on the answers given to a parliamentary survey (Stefan 2010) in order to create a hierarchy of committee salience. More precisely, a battery of questions asked the MPs to name the 3 most important standing committees. The corresponding variable is coded 2 if the MP is a member of one the most mentioned committees: budget \& finance (145 mentions or $29.6 \%$ of all mentions), legal affairs, discipline \& immunities (124 mentions or $25.3 \%$ ), administration, public works \& environment (51 mentions or $10.4 \%$ ) and labour \& social protection (48 mentions or $9.8 \%$ ). It takes the value of 1 for MPs in the economic policies, education \& science, rules, industry, agriculture \& forestry committees (3-4\% of the mentions). The remaining 8 committees, which were either never mentioned or mentioned very rarely, are coded as 0 .

Table 1: Classification of committee by type of output

\begin{tabular}{llll}
\hline Distributive & High Policy & Public Goods & Base \\
\hline Administration \& public works & Defence & Education \& science & Abuses \& corruption \\
Agriculture \& forestry & Finance & Health \& family & Culture \\
& Foreign affairs & Labour \& social protection & Diaspora \\
& Legal affairs & Economy \\
& EU affairs & & Human rights \\
& & Industry \\
& & IT \& C \\
\end{tabular}


Overall, there is a moderate association between the two dependent variables, the committee salience ordinal measure and the nominal variable focusing on the committees' types of output, with Cramer's V $=0.456$. This correlation is driven by a number of regularities: none of the base committees made it in 'the most important' category based on MPs' answers, while both distributive committees avoided the 'least important' category. There is more heterogeneity with respect to the 'high policy' committees: roughly half of them were included in 'the most important' category and the other half appear in the 'least important' category.

Independent variables

Sector knowledge indicates whether the MP has formal education and professional expertise in the area of the committee she was assigned to. The variable takes the value of 0 if the MP has neither education nor a profession that would match the committee's jurisdiction, 1 if the MP has only one of the attributes and 2 if her $\mathrm{CV}$ displays both elements.

Committee seniority is a dichotomous indicator for whether the MP has served in a past term in the committee she was assigned this time.

Length of parliamentary career reports the number of years of membership in Parliament before the current analyzed term. An MP is coded as National party leader if she serves in the party's national executive bodies. Chamber office is a dummy variable coded 1 for the MPs who served in the Permanent Bureau of the Chamber during that legislative cycle.

Electoral security indicates the extent to which the MP's election was safe and certain or, on the contrary, the legislator barely won her seat. Its measurement differs for the first 4 terms compared to 5th term because of the 2008 electoral reform (Giugal et al 2017) that replaced closed-list PR with an original mixed-member proportional system in which all MPs were elected from single member districts (SMDs). For the MPs elected from closed list PR the variable is computed by subtracting the MP's list placement from the number of seats won by their party in the constituency. For the MPs elected in 2008 the variable subtracts the effective electoral threshold ${ }^{3}$ from the share of votes won by the MP. Both sets of values for this variable are rescaled on a 0 to 1 scale to facilitate the comparison of the effects.

District magnitude (log) indicates the natural logarithm of the MPs' district magnitude. Between 1992 and 2004 the district magnitude varied between 4 and 29. At the 2008 elections the constituencies (i.e. counties) were subdivided in SMDs. For this latter term we used the natural logarithm of the number of SMDs in the county.

Share working in agriculture in constituency indicates the percentage of citizens in the county of the MP having agriculture as their main occupation in the year that marked the start of the legislative term. Similarly, Share unemployed in constituency reports the average percentage of citizens in the county of the MP who were unemployed in the 4 years that preceded the start of the term. 


\subsection{Methods}

The statistical analyses are conducted in two stages. First, I analyse which factors contribute to the assignment of MPs to high policy, distributive, public goods or other committees. Then, I investigate the role played by the same factors in assignment to more or less important committees.

Given that the dependent variable in the first series of analyses is categorical, and distinguishes between assignment to the four types of committees mentioned above, the most appropriate estimation method is a multinomial regression (Long \& Freese, 2006). The dependent variable in the second series of analyses is ordinal and distinguishes between assignment to committees based on their importance: least important, mixed importance and most important committees. I therefore use an ordered logistic regression (Long \& Freese, 2006). Both series of analyses include legislative term fixed effects to ensure that the results are not driven by time effects.

\subsection{Who gets what? Assignment patterns and committees outputs}

The results of the multinomial logistic regressions are reported in Table 2 below. The reference outcome is always assignment to a base committee. I report and interpret the relative risk ratios, not the raw estimates. The models include robust standard errors clustered by MP to account for multiple committee memberships in the same term. The second model includes the two districtrelated variables that indicate the level of unemployment in the county and the share of constituents working in agriculture. Overall, the explanatory power of the models is relatively modest.

MPs assigned to public goods committees tend to have more knowledge and professional expertise regarding the policy area of their committee than their colleagues assigned to base committees. The same is true for MPs who are allocated seats in committees with a distributive potential, although the effect is somewhat smaller. The left side panel of Figure 1 below plots the predicted probabilities of membership in each of the four types of committees, associated with the values for this variable. The figure is based on model 2 in Table 2 . The results also indicate there are considerably more MPs with committee seniority serving in high policy committees than in base committees. This effect is even stronger for the MPs who serve in the distributive committees. 
Figure 1: Sector knowledge, gender and committee assignment

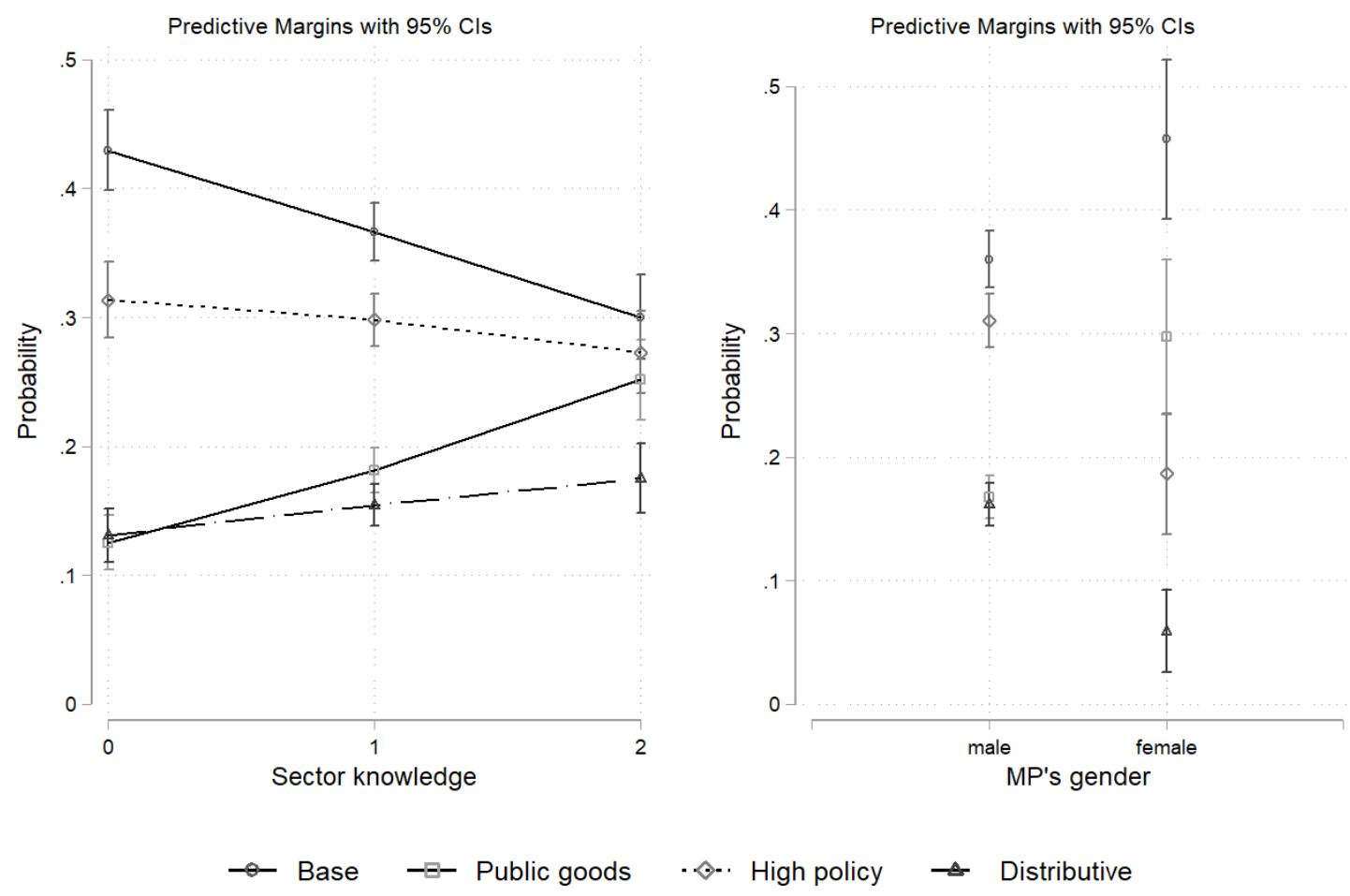

The length of one's parliamentary career appears to matter only for assignment to the distributive committees. Thus, veteran MPs are less likely to be assigned to committees with a distributive potential than those legislators who are just starting their careers. Nevertheless, the effect is not very strong: newcomer MPs have a 0.17 probability to receive a seat in distributive committees whereas for the MPs with the longest careers (18 years in the Parliament prior to current term) the corresponding probability is 0.05 . 
Table 2: Determinants of assignment by type of committee output (1992-2012)

\begin{tabular}{|c|c|c|c|c|c|c|}
\hline & \multicolumn{2}{|c|}{ Public Goods } & \multicolumn{2}{|c|}{ High policy } & \multicolumn{2}{|c|}{ Distributive } \\
\hline & M1 & M2 & M1 & M2 & M1 & M2 \\
\hline Sector knowledge & $\begin{array}{l}1.70 * * * \\
(0.13)\end{array}$ & $\begin{array}{l}1.71 * * * \\
(0.13)\end{array}$ & $\begin{array}{l}1.11 \\
(0.07)\end{array}$ & $\begin{array}{l}1.12 \\
(0.08)\end{array}$ & $\begin{array}{l}1.39 * * * \\
(0.11)\end{array}$ & $\begin{array}{l}1.40 * * * \\
(0.11)\end{array}$ \\
\hline Committee seniority & $\begin{array}{l}1.49 \\
(0.38)\end{array}$ & $\begin{array}{l}1.49 \\
(0.39)\end{array}$ & $\begin{array}{l}2.07 * * * \\
(0.41)\end{array}$ & $\begin{array}{l}2.04 * * * \\
(0.41)\end{array}$ & $\begin{array}{l}2.55^{* * *} \\
(0.66)\end{array}$ & $\begin{array}{l}2.52 * * * \\
(0.66)\end{array}$ \\
\hline Length of parliamentary career & $\begin{array}{l}0.96 \\
(0.03)\end{array}$ & $\begin{array}{l}0.96 \\
(0.03)\end{array}$ & $\begin{array}{l}0.99 \\
(0.02)\end{array}$ & $\begin{array}{l}0.99 \\
(0.02)\end{array}$ & $\begin{array}{l}0.91 * * * \\
(0.03)\end{array}$ & $\begin{array}{l}0.91 * * * \\
(0.03)\end{array}$ \\
\hline Chamber office & $\begin{array}{l}0.84 \\
(0.29)\end{array}$ & $\begin{array}{l}0.86 \\
(0.30)\end{array}$ & $\begin{array}{l}1.17 \\
(0.27)\end{array}$ & $\begin{array}{l}1.17 \\
(0.27)\end{array}$ & $\begin{array}{l}1.74 * \\
(0.55)\end{array}$ & $\begin{array}{l}1.86 * * \\
(0.58)\end{array}$ \\
\hline National leader & $\begin{array}{l}0.92 \\
(0.15)\end{array}$ & $\begin{array}{l}0.90 \\
(0.15)\end{array}$ & $\begin{array}{l}1.18 \\
(0.15)\end{array}$ & $\begin{array}{l}1.18 \\
(0.16)\end{array}$ & $\begin{array}{l}0.63 * * \\
(0.11)\end{array}$ & $\begin{array}{l}0.63 * * \\
(0.12)\end{array}$ \\
\hline Electoral security & $\begin{array}{l}0.70 \\
(0.48)\end{array}$ & $\begin{array}{l}0.79 \\
(0.56)\end{array}$ & $\begin{array}{l}2.32 \\
(1.34)\end{array}$ & $\begin{array}{l}2.46 \\
(1.44)\end{array}$ & $\begin{array}{l}1.74 \\
(1.26)\end{array}$ & $\begin{array}{l}1.73 \\
(1.29)\end{array}$ \\
\hline District magnitude (log) & $\begin{array}{l}1.08 \\
(0.15)\end{array}$ & $\begin{array}{l}1.27 \\
(0.20)\end{array}$ & $\begin{array}{l}1.16 \\
(0.13)\end{array}$ & $\begin{array}{l}1.19 \\
(0.16)\end{array}$ & $\begin{array}{l}0.78 \\
(0.12)\end{array}$ & $\begin{array}{l}1.01 \\
(0.18)\end{array}$ \\
\hline Female MP & $\begin{array}{l}1.45^{* *} \\
(0.27)\end{array}$ & $\begin{array}{l}1.41^{*} \\
(0.27)\end{array}$ & $\begin{array}{l}0.47 * * * \\
(0.09)\end{array}$ & $\begin{array}{l}0.47 * * * \\
(0.09)\end{array}$ & $\begin{array}{l}0.29 * * * \\
(0.10)\end{array}$ & $\begin{array}{l}0.28 * * * \\
(0.09)\end{array}$ \\
\hline Age & $\begin{array}{l}1.02 * * * \\
(0.01)\end{array}$ & $\begin{array}{l}1.02 * * * \\
(0.01)\end{array}$ & $\begin{array}{l}0.99 \\
(0.01)\end{array}$ & $\begin{array}{l}0.99 \\
(0.01)\end{array}$ & $\begin{array}{l}1.01^{*} \\
(0.01)\end{array}$ & $\begin{array}{l}1.01 * \\
(0.01)\end{array}$ \\
\hline Share working in agriculture in constituency & & $\begin{array}{l}1.01 \\
(0.01)\end{array}$ & & $\begin{array}{l}1.01 \\
(0.01)\end{array}$ & & $\begin{array}{l}1.02 * * * \\
(0.01)\end{array}$ \\
\hline Share unemployed in constituency & & $\begin{array}{l}1.03 \\
(0.03)\end{array}$ & & $\begin{array}{l}0.99 \\
(0.02)\end{array}$ & & $\begin{array}{l}1.06 * * \\
(0.03)\end{array}$ \\
\hline Term fixed effects & Yes & Yes & Yes & Yes & Yes & Yes \\
\hline $\mathrm{N}$ & 1849 & 1832 & 1849 & 1832 & 1849 & 1832 \\
\hline McFadden's R ${ }^{2}$ & 0.041 & 0.045 & 0.041 & 0.045 & 0.041 & 0.045 \\
\hline
\end{tabular}

Notes: Significance at $* \mathrm{p}<0.10,{ }^{* *} \mathrm{p}<0.05,{ }^{* * *} \mathrm{p}<0.01$

Cell entries are relative risk ratios. Robust standard errors clustered by MP in parentheses. 
Members of the Permanent Bureau of the Chamber are almost twice as likely to serve in a distributive committee compared to their colleagues who do not hold such office. Similarly, the national leadership variable makes a difference only for the distributive committees - but it seems that MPs who are members of the national executive of their party are less likely to serve in such committees than MPs who do not have this position.

MPs who are more vulnerable electorally seem less likely to receive a seat in high policy committees and in those having a distributive potential, although the variable does not reach conventional levels of statistical significance. The same is true for district magnitude as five of the six coefficients point in the expected direction, but they are not statistically significant. Higher district magnitude MPs appear more likely to serve in public goods and high policy committees than MPs elected from lower district magnitude and the reverse is true for distributive committees.

As expected, it is clearly more difficult for women MPs to be assigned to high policy or distributive committees compared to their male counterparts. Moreover, women MPs are much more likely to serve in the public goods committees, which deal with feminised policy topics such as health, family and social protection. These differences are illustrated in the right side panel of Figure 1 above. Older MPs are nominated more often to public goods and distributive committees compared to their colleagues who are more young.

The regressions in model 2 corroborate the findings discussed until now. Additionally, the two district characteristics seem to matter only for the assignment to distributive committees. In line with our expectations, MPs representing counties with higher levels of unemployment and more citizens working in agriculture have a higher chance of being assigned to distributive committees.

In an alternative model (presented in Table A1.1 in the Online Appendix I ran the multinomial logistic regressions separately for each term. These disaggregated analyses can assess whether the 2008 electoral reform, which introduced stronger incentives to cultivate a personal vote, also led to changes in committee assignment patterns. There is very little evidence in this direction: the coefficients for the two variables that could capture this change, district magnitude and electoral security do not change direction and do not reach statistical significance. ${ }^{4}$ These sets of regressions also illustrated the consistent effect of sector knowledge and gender across parliamentary terms. Similarly, MPs representing districts with a higher share of citizens working in agriculture were more likely to be assigned to distributive committees in three of the five terms analyzed.

\subsection{Assignment patterns and committee salience}

The evidence in favour of the informational logic of committee assignment illustrated above with respect to the four types of committee outputs seems to be even stronger when we take into account the distribution of seats in more or less important committees. The results of the ordered logistic regressions which have as the dependent variable the level of committee salience as perceived by legislators are reported in Table 3 below. 
MPs assigned to the most important committees tend to have more sector knowledge than their colleagues assigned to the least important committees. Based on model 2 in Table 3, the left panel of Figure 2 below plots the predicted probabilities of membership in each of the three types of committees depending on the level of sector knowledge. While sector knowledge does not make a difference for committees with a mixed level of salience, its effect is considerable for the probability of serving in the other two types of committees.

\section{Table 3: Determinants of assignment to the most important committees}

\begin{tabular}{|c|c|c|}
\hline & M1 & M2 \\
\hline Sector knowledge & $\begin{array}{l}1.64 * * * \\
(0.81)\end{array}$ & $\begin{array}{l}1.63 * * * \\
(0.81)\end{array}$ \\
\hline Committee seniority & $\begin{array}{l}1.52 * * * \\
(0.23)\end{array}$ & $\begin{array}{l}1.50 * * * \\
(0.23)\end{array}$ \\
\hline Length of parliamentary career & $\begin{array}{l}0.95 * * * \\
(0.02)\end{array}$ & $\begin{array}{l}0.95 * * * \\
(0.02)\end{array}$ \\
\hline Chamber office & $\begin{array}{l}1.07 \\
(0.22)\end{array}$ & $\begin{array}{l}1.07 \\
(0.22)\end{array}$ \\
\hline National leader & $\begin{array}{l}0.74 * * * \\
(0.08)\end{array}$ & $\begin{array}{l}0.74 * * * \\
(0.08)\end{array}$ \\
\hline Electoral security & $\begin{array}{l}2.44 * * \\
(1.03)\end{array}$ & $\begin{array}{l}2.51^{* *} \\
(1.09)\end{array}$ \\
\hline District magnitude (log) & $\begin{array}{l}0.88 \\
(0.08)\end{array}$ & $\begin{array}{l}0.86 \\
(0.09)\end{array}$ \\
\hline Female MP & $\begin{array}{l}0.60 * * * \\
(0.10)\end{array}$ & $\begin{array}{l}0.60 * * * \\
(0.10)\end{array}$ \\
\hline Age & $\begin{array}{l}0.99 * * * \\
(0.00)\end{array}$ & $\begin{array}{l}0.99 * * * \\
(0.00)\end{array}$ \\
\hline$\%$ working. in agriculture in constituency & & $\begin{array}{l}1.00 \\
(0.00)\end{array}$ \\
\hline$\%$ unemployed in constituency & & $\begin{array}{l}1.01 \\
(0.02)\end{array}$ \\
\hline Term fixed effects & Yes & Yes \\
\hline Cutpoint 1 & $\begin{array}{l}-0.15 \\
(0.34)\end{array}$ & $\begin{array}{l}-0.12 \\
(0.42)\end{array}$ \\
\hline Cutpoint 2 & $\begin{array}{l}1.21 \\
(0.34)\end{array}$ & $\begin{array}{l}1.24 \\
(0.42)\end{array}$ \\
\hline $\mathrm{N}$ & 1849 & 1832 \\
\hline McFadden's $\mathrm{R}^{2}$ & 0.039 & 0.039 \\
\hline
\end{tabular}


Notes: Significance at $* \mathrm{p}<0.10,{ }^{* *} \mathrm{p}<0.05,{ }^{* * *} \mathrm{p}<0.01$

Cell entries are odds ratios. Robust standard errors clustered by MP in parentheses.

A very similar pattern is observed for committee seniority, which has a positive effect on the likelihood of being assigned to an important committee, no effect for the mixed committees and decreases the probability of serving in one of the least important parliamentary committees. A certain division of labour can be observed as MPs who hold a Chamber leadership position or are members of the national leadership of their parties do not have a higher chance of receiving a seat in the most important committees. For the latter variable, the models even indicate a negative effect. Electorally vulnerable MPs are significantly less likely to be assigned to the most important committees. The right side panel of Figure 2 below illustrates that the probability of receiving a seat in such a committee is almost $20 \%$ smaller for the most vulnerable MPs compared to those who had the most secure seats which corroborates our expectation.

\section{Figure 2: Sector knowledge, electoral security and assignment to important committees}

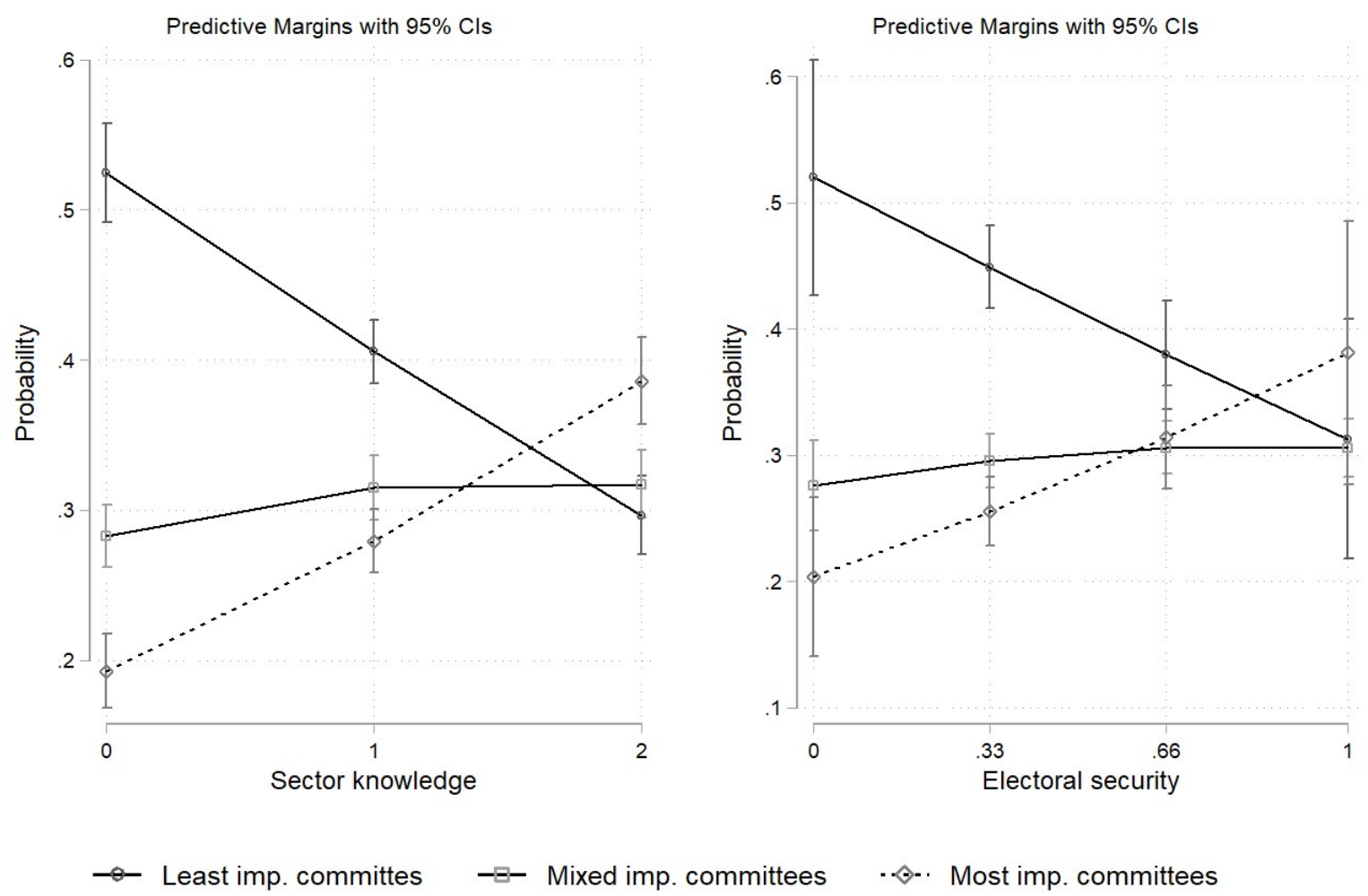

MPs with longer parliamentary careers do not have a better chance of being assigned to the most important committees. On the contrary, they find themselves more often in less important 
committees as they advance in their legislative careers. This effect is illustrated in the left side panel of Figure 3 below. One possible explanation is that these MPs are closer to retirement and thus less interested in fighting for a position in such a committee. From an informational perspective, it also makes sense that party gatekeepers value more other credentials (e.g. policy expertise, seniority in that particular committee) than parliamentary seniority when they decide on the membership in these committees.

In line with the previous interpretation regarding the anticipation of retirement, older legislators have limited access to more important committees. This is yet another finding that corroborates the assignment patterns which distinguished between committees based on their output. The institutional (district magnitude) and socio-economic features (average unemployment rate and the salience of agriculture as occupation) of the district do not make any difference with respect to assignment to more or less important committees.

Similar to the findings reported regarding the output-based committee assignment, female legislators are less likely to serve in the most important committees. The right side panel of Figure 3 below illustrates that while the probability for male MPs to serve in these committees is $29 \%$, for female MPs it is only $20 \%$, all other things being equal.

In an alternative model (presented in Table A1.2 in the Appendix) I estimated the ordered logistic regressions separately for each term. Sector knowledge was the only predictor that had a substantive positive effect on assignment to an important committee in each of the five terms. Another result that stands out is that after the 2008 electoral reform the MPs who had the highest levels of electoral security were much more likely to be assigned to the most important committees, whereas in the previous terms this variable did not make any difference. 
Figure 3: Length of parliamentary career and assignment to important committees

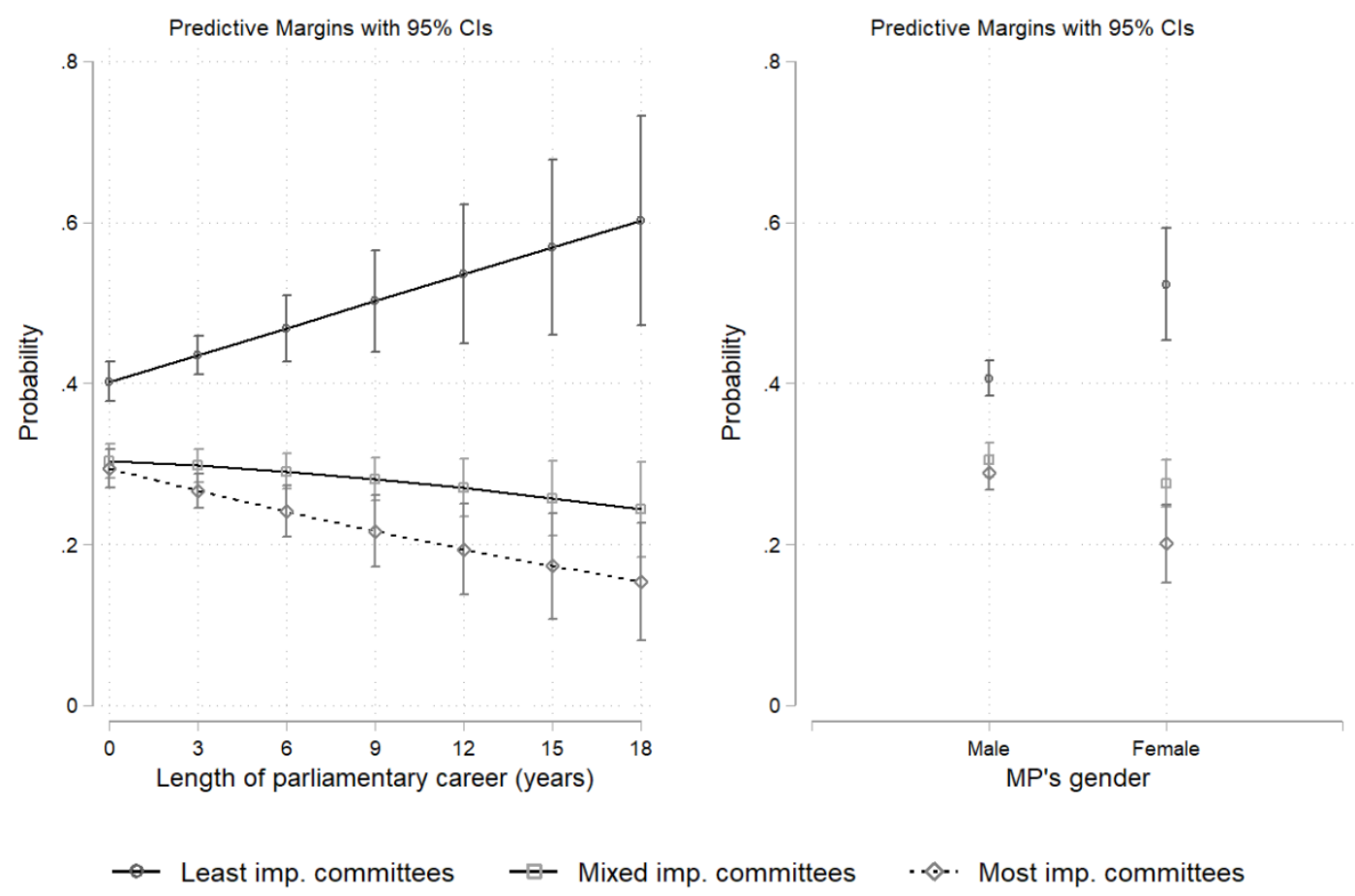

\section{Conclusion}

This article set out to study the patterns of committee assignment in a young democracy, hoping to shed light on how the informational, partisan and distributive logics of legislative organization can be adapted to such a context and to test their explanatory potential. At the same time, the article tested whether the assignment of members to committees is also gendered. While much of the variation in committee membership in Romania remains unexplained, the research does find evidence in favour of the idea that committee assignment is used to facilitate a low-cost policy specialization of legislators, based on their past professional expertise and education. Normatively, this is a positive finding, given the testing conditions under which young legislatures operate after regime change, particularly the lack of relevant in-house expertise and experience in legislative policy-making.

There is also partial evidence in favour of the distributive theory. Whereas, features directly related to the circumstances of election (i.e. marginality, district magnitude) do not matter for assignment, the study reveals a link between the characteristics of the MP's district and her likelihood to serve in a committee that has the potential to produce policies with localised benefits. This refers to the case of agricultural committees and agricultural districts.

The models produce no evidence that party leaders reserve for themselves seats in the committees dealing with high policy - which goes against the findings of Riera and Cantú (2018) - in fact, they are less likely to serve in the most important committees. The partisan logic of committee organization could be tested further by analyzing whether patterns of assignment depend on the salience political parties attach to the policy jurisdictions of the committees. Even 
in a context with weak programmatic linkages, like the Romanian one, previous research (Gherghina and Chiru 2018) has shown that the extent to which opposition parties support or oppose government legislation at roll-call votes is in part driven by the salience they allocate to the corresponding policy domain. Future studies could also explore the mechanisms behind the gendered committee assignment patterns revealed here: are women MPs overtly marginalised by the committee gatekeepers or is it more the case that the assignment follows different gendered preferences (e.g. women MPs preferring to serve in public good committees more than male legislators)?

\section{References}

Andre A., Depauw, S. and Martin, S. (2016) Trust is good, control is better: multiparty government and legislative organization. Political Research Quarterly 69(1): 108-120.

Bækgaard, M., \& Kjaer, U. (2012). The gendered division of labor in assignments to political committees: Discrimination or self-selection in Danish local politics?. Politics \& Gender, 8(4), 465-482.

Chiru, M. (2019) "Loyal soldiers or seasoned leaders? The selection of committee chairs in the European Parliament", Journal of European Public Policy, DOI: 10.1080/13501763.2019.1600573.

Chiru, M., and Gherghina, S. (2017). Committee chair selection under high informational and organizational constraints. Party Politics, DOI: 10.1177/1354068817741765.

Chiru, M., \& Popescu, M. (2017). The Value of Legislative Versus Electoral Experience and Gender in Explaining Candidate List Placement in Closed-List PR. Problems of Post Communism, 64(2), 65-78.

Ciftci, S., Forrest, W., \&Tekin, Y. (2008). Committee assignments in a nascent party system: The case of the Turkish Grand National Assembly. International Political Science Review, 29(3), 303-324.

Cox, G. and McCubbins, M. (1993). Legislative Leviathan: Party Government in the House. Berkeley: Cambridge University Press 
Dubrow, J. K. (2006). Women's Representation in the Romanian Chamber of Deputies, 19922005: The Effect of District Economic Development. International Journal of Sociology, 36(1), 93-109.

Espírito-Santo, A., \& Sanches, E. R. (2019). Who Gets What? The Interactive Effect of MPs' Sex in Committee Assignments in Portugal. Parliamentary Affairs.

Frye, T. (2002). The perils of polarization: Economic performance in the postcommunist world. World Politics, 54(3), 308-337.

Gherghina, S., and Chiru, M. (2013) Declaraţii de intenţie sau proiecţii de politici publice? Programele electorale ale partidelor românești la alegerile legislative din 2012, Cluj: CA Publishing.

Gherghina, S., and Chiru, M. (2018) 'Romania: An Ambivalent Parliamentary Opposition' in De Giorgi, E., Ilonszki. G. (eds.) Opposition Parties in European Legislatures:

Responsiveness Without Responsibility?, Routledge, pp. 191-210.

Gilligan, T. W. and Krehbiel, K. (1990) 'Organization of Informative Committees by a Rational Legislature', American Journal of Political Science, 34(2), 531-564.

Giugal, A., Johnston, R., Chiru, M., Ciobanu, I., \& Gavris, A. (2017). Gerrymandering and Malapportionment, Romanian Style: The 2008 Electoral System. East European Politics and Societies, 31(4), 683-703.

Hansen, M. E. (2011). A random process? Committee assignments in DáilÉireann. Irish Political Studies, 26(3), 345-360.

Heath, M. R., Schwindt-Bayer, L. A., \& Taylor-Robinson, M. M. (2005). Women on the sidelines: Women's representation on committees in Latin American legislatures. American Journal of Political Science, 49(2), 420-436.

Ibenskas, R., \& Sikk, A. (2017). Patterns of party change in Central and Eastern Europe, 19902015. Party Politics, 23(1), 43-54.

Ionescu, I. N. (201) Le Rôle du Parlement Dans La Creation Des Politiques Publiques En Roumanie Postcommuniste. Iasi: Institutul European.

Long, J. S., and Freese, J. (2006). Regression models for categorical and limited dependent variables using Stata (2nd ed.). College Station, TX: Stata Press.

Mainwaring, S., Gervasoni, C. and España-Najera, A., 2017. Extra-and within-system electoral volatility. Party Politics, 23(6): 623-635.

Martin, S. (2011) Electoral institutions, the personal vote, and legislative organization. Legislative Studies Quarterly, 36(3), 339-361.

Martin, S. (2014) "Committees" in: Martin, S., Saalfeld, T. \& Strøm, K. (eds.), The Oxford Handbook of Legislative Studies. Oxford: Oxford University Press, pp. 352-368.

Mershon, C., \& Shvetsova, O. (2009). Timing matters: incentives for party switching and stages of parliamentary cycles. In Heller, W. B. \& Mershon, C. (eds.)Political parties and legislative party switching. Palgrave Macmillan, New York, pp. 201-229

Mickler, T. A. (2018a). Who gets what and why? Committee assignments in the German Bundestag. West European Politics, 41(2), 517-539.

Mickler, T. A. (2018b). Not so random after all?-revisiting committee assignments in Dáil Éireann. Irish Political Studies, 33(1), 112-135.

Millard, F. 2004. Elections, Parties, and Representation in Post-Communist Europe, Houndmills: Palgrave MacMillan. 
Olson, D. M., Crowther, W. E. (Eds.). (2002). Committees in Post-Communist Democratic Parliaments: Comparative Institutionalization. Ohio State University Press.

Pansardi, P., \& Vercesi, M. (2017). Party gate-keeping and women's appointment to parliamentary committees: Evidence from the Italian case. Parliamentary Affairs, $70(1)$, 62-83.

Pekkanen, R., Nyblade, B., \& Krauss, E. S. (2006). Electoral incentives in mixed-member systems: party, posts, and zombie politicians in Japan. American Political Science Review, 100(2), 183-193.

Raymond, C. D., \& Holt, J. (2019). Constituency Preferences and Assignment to Agriculture Committees. Parliamentary Affairs, 72(1), 141-161.

Riera, P., \& Cantú, F. (2018). Determinants of legislative committee membership in proportional representation systems. Party Politics, 24(5), 524-535.

Roper, S. D. (2004) 'Parliamentary Development', in Carey, H. F. \&, Manea, N. (eds.), Romania since 1989: Politics, Economics and Society, Lexington Books, Lanham, pp. 159-177.

Shepsle, K. A. and Weingast, B. R. (1982) „Institutionalizing Majority Rule: A Social Choice Theory with Policy Implications ${ }^{\text {ee }}$, The American Economic Review,72, 367-371.

Stefan, L. (2010) Survey of the Romanian Chamber of Deputies. Machine readable data files. Spirova, M. (2007) Political Parties in Post-communist Societies. Formation, Persistence, and Change, Houndmills: Palgrave MacMillan.

Taylor-Robinson, M. M. (2014) Gender and legislatures. In Martin, S., Saalfeld, T., \& Strøm, K. (Eds.). (2014). The Oxford handbook of legislative studies. Oxford: Oxford University Press, pp. 250-266

Tufis, C. D. (2015a). "Studii Electorale Românești: Parlamentari Români 1992-1996 (SERPROM-1992)", FSPUB / IDC / RQSA, București, DOI:

10.13140/RG.2.1.2115.8569

Tufis, C. D. (2015b). "Studii Electorale Românești: ParlamentariRomâni 1996-2000 (SERPROM-1996)", FSPUB / IDC / RQSA, București, DOI:

10.13140/RG.2.1.2720.0169

Tufis, C. D. (2015c). "Studii Electorale Românești: ParlamentariRomâni 2000-2004 (SERPROM-2000)", FSPUB / IDC / RQSA, București, DOI:

10.13140/RG.2.1.1221.1361

Tufis, C. D. (2015d). "Studii Electorale Românești: ParlamentariRomâni 2004-2008 (SERPROM-2004)", FSPUB / IDC / RQSA, București, DOI: 10.13140/RG.2.1.4095.4726

Tufis, C. D. (2015e). "Studii Electorale Românești: ParlamentariRomâni 2008-2012 (SERPROM-2008)", FSPUB / IDC / RQSA, București, DOI: 10.13140/RG.2.1.1364.6566

Ylaoutinen S and Hallerberg M (2009) The role of parliamentary committees in the budgetary process in the Central and Eastern European countries. In: Ganghof S, Honnige $\mathrm{C}$ and Stecker C (eds), Parlamente, Agendasetzung und Vetospieler: Festschrift fur Herbert Doring. Wiesbaden, Germany: VS Verlag, pp. 147-174.

*** Regulamentul Camerei Deputatilor. 1994. Available at: https://www.ilegis.ro/oficiale/index/act/38353 
${ }^{1}$ Unfortunately, this prediction cannot be tested directly because electronic records of roll-call votes were introduced only in 2006.

${ }^{2}$ The Standing Orders of the Chamber of Deputies adopted in 1994 specified a different threshold: 13-40 members. ${ }^{3}$ This is computed as: $0.75 /(\mathrm{M}+1)$, where $\mathrm{M}$ is the district magnitude

${ }^{4}$ An exception is that MPs elected from larger district magnitudes in 2008 are more likely to be assigned to a high policy committee, whereas in the previous terms the variable exhibited the same direction but was not statistically significant. 